\title{
ANALISIS SISTEM PENJAMINAN MUTU PENDIDIKAN PADA SMA YANG TERAKREDITASI A
}

\author{
Bella Ghia Dimmera ${ }^{11}$ dan Pebria Dheni Purnasari ${ }^{2)}$ \\ ${ }^{1}$ Manajemen, Institut Shanti Bhuana \\ ${ }^{2}$ Pendidikan Guru Sekolah Dasar, Institut Shanti Bhuana \\ 1,2 Jl. Bukit Karmel No.1, Bengkayang, Kalimantan Barat, 79211 \\ E-mail: bellaghia@shantibhuana.ac.id ${ }^{1)}$,pebria.dheni@shantibhuana.ac.id ${ }^{2)}$
}

\begin{abstract}
ABSTRAK
Penelitian ini tujuannya adalah untuk mendeskripsikan sistem penjaminan mutu pendidikan pada SMA yang ter-akreditasi A yang letaknya di Kabupaten Bengkayang. Pendekatan dalam penelitian ini menggunakan pendekatan kualitatif untuk memperoleh data yang bersifat deskriptif, sedangkan observasi, wawancara mendalam, dan dokumentasi sebagai teknik pengumpulan data. Data yang diperoleh dari berbagai sumber harus di verifikasi dengan menggunakan teknik triangulasi data. Triangulasi data dalam penelitian ini dilakukan untuk memvalidasi data ataupun informasi dari berbagai sumber yaitu Kepala sekolah, tim penjaminan mutu, guru, peserta didik, dan komite sekolah. Kajian terhadap implementasi sistem penjaminan mutu pendidikan dapat memberikan informasi bagi sekolah untuk meningkatkan mutu pendidikan secara berkelanjutan. Hasil penelitian menunjukkan bahwa pada dua SMA yang mendapatkan peringkat akreditasi A, yaitu SMA N 1 Bengkayang dan SMA N 3 Bengkayang implementasi sistem penjaminan mutu pendidikannya sudah berjalan dengan baik, mencakup: penetapan standar mutu sesuai dengan kriteria minimal dalam Standar Nasional Pendidikan (SNP) dengan melibatkan seluruh komponen sekolah, pemetaan mutu melalui kegiatan evaluasi diri, penyusunan rencana mutu berdasarkan hasil pemetaan mutu yang telah dilakukan, pelaksanaan rencana pemenuhan mutu dengan terwujudnya budaya mutu, evaluasi atau audit pelaksanaan rencana pemenuhan mutu untuk meningkatkan mutu sekolah secara terus menerus. Pada SMA yang ter-akreditasi A tersebut dapat dibuktikan bahwa pengelolaan kebijakan, regulasi, program, kegiatan, telah sesuai dengan tata cara prosedur yang ditetapkan mengenai Standar Nasional Pendidikan, serta dapat dipercaya dan disepakati bersama oleh seluruh komponen sekolah, meskipun masih ada beberapa kendala dalam penerapannya.
\end{abstract}

Kata kunci: Penjaminan Mutu Pendidikan, Standar Nasional Pendidikan, Akreditasi

\section{PENDAHULUAN}

Pencapaian keberhasilan tujuan nasional pendidikan dapat ditandai dengan implementasinya sistem penjaminan mutu pendidikan. Mutu pendidikan yang bahwasanya harus dilakukan secara berkelanjutan akan dapat mencapai tujuan nasional pendidikan yang bermutu tinggi. Oleh karena itu, Pemerintah telah mengamanatkan penyusunan 8 (delapan) Standar Nasional Pendidikan sebagaimana diatur dalam Peraturan Pemerintah Nomor 57 Tahun 2021 tentang Standar Nasional Pendidikan yang dapat dijadikan pedoman untuk mewujudkan penjaminan mutu pendidikan. Standar Nasional Pendidikan sesuai Peraturan Pemerintah Nomor 57 Tahun 2021 Pasal 3 ayat 1 mencakup kriteria minimal tentang sistem pendidikan di seluruh wilayah hukum Negara Kesatuan Republik Indonesia. Adapun komponen Standar Nasional Pendidikan terdiri dari delapan standar yaitu standar isi, standar proses, standar kompetensi lulusan, standar pendidik dan tenaga kependidikan, standar sarana dan prasarana, standar pengelolaan, standar pembiayaan, dan standar penilaian pendidikan.

Mutu adalah kualitas memenuhi atau melampaui harapan pemangku kepentingan. Sedangkan penjaminan mutu adalah proses penetapan dan pengimplementasian standar mutu manajemen secara berkelanjutan agar terpenuhinya kepuasan pemangku kepentingan. sistem penjaminan mutu pendidikan pada satuan pendidikan, meliputi keseluruhan aspek penyelenggaraan pendidikan dengan memanfaatkan seluruh sumber daya yang ada dalam untuk mencapai Standar Nasional Pendidikan. Satuan pendidikan menerapkan seluruh siklus sistem penjaminan mutu secara mandiri dan berkesinambungan untuk membangun budaya mutu pada satuan pendidikan (Mukaromah, 2019).

Capaian pemenuhan Standar Nasional Pendidikan menjadi salah satu syarat penting yang harus diimplementasikan setiap sekolah sebagai lembaga pendidikan agar sistem penjaminan mutu pendidikan sesuai dengan apa yang diharapkan. Hal ini diungkapkan juga oleh (Asmara, 2015) bahwa implementasi delapan standar nasional pendidikan menjadi upaya penting setiap sekolah/madrasah dalam menjamin kualitas pendidikan yang dikelolanya. Namun, di Kabupaten Bengkayang masih banyak sekolah yang belum benarbenar melaksanakan budaya mutu yang pada akhirnya menyebabkan kesulitan dalam memenuhi Standar Nasional Pendidikan. Beberapa sekolah di Kabupaten 
Bengkayang sudah menerapkan sistem penjaminan mutu pendidikan sebagai acuan agar sekolah memiliki ramburambu yang bisa dijadikan landasan dalam penyelenggaraan program sekolah secara terstruktur dan terukur, tetapi dalam pelaksanaannya masih ada yang belum sesuai dengan standar mutu yang telah ditetapkan.

Menurut (Rahmania, 2020) terdapat beberapa faktor yang menjadi kendala dalam penerapan sistem penjaminan mutu internal. Diantara faktor dan solusi tersebut adalah masalah keuangan dalam proses pelaksanaan penjaminan mutu, serta fasilitas dalam proses peningkatan mutu karena tidak semuanya dibiayai oleh sekolah tetapi hanya menerima dana dari Bantuan Operasional Sekolah (BOS), sehingga sekolah berusaha mencari dana dari pemerintah atau nonpemerintah. Selain itu, kualitas proses pengisian formulir juga menjadi salah satu faktor yang mengganggu seperti terkadang secara teknis ada masalah jaringan yang mengganggu proses pengisian formulir, hal ini mengakibatkan kualitas laporan yang buruk. Untuk itu sekolah harus dapat beradaptasi dengan keadaan, sehingga sekolah berusaha sebaik mungkin saat mengisi formulir, dengan cara mencari waktu luang agar dapat fokus dalam pengisian formulir tersebut.

Pelaksanaan sistem penjaminan mutu pendidikan di seluruh penjuru daerah mempunyai banyak kendala dalam penerapannya, terutama Kabupaten Bengkayang yang letaknya di daerah perbatasan. Penyebab permasalahan tersebut dipengaruhi beberapa faktor antara lain pelaksanaan proses pembelajaran belum sesuai dengan standar, sarana prasarana yang belum memadai, kecukupan tenaga pendidik maupun tenaga kependidikan belum terpenuhi. Hal tersebut menunjukkan bahwa mutu pendidikan di Kabupaten Bengkayang masih memprihatinkan. Permasalahan yang dihadapi setiap sekolah untuk memenuhi kriteria sekolah yang bermutu masih jauh dari harapan.

Menyadari hal ini, evaluasi berbasis data dapat dilaksanakan dengan program dan kegiatan untuk memenuhi Standar Nasional Pendidikan. Dengan demikian, pelaksanaan program harus dipantau dan dievaluasi berdasarkan pada keefektifan dan keefisienan pemanfaatan sarana prasarana, pendanaan, dan sumber daya yang ada. Analisis sistem penjaminan mutu pendidikan digunakan sebagai acuan untuk mengetahui pengimplementasian sistem penjaminan mutu pendidikan yang dapat dilihat dari hasil capaian semua komponen pendukungnya (Muhammad, Hamid, 2016). Tahapan dari siklus penjaminan mutu tersebut dianalisis secara terperinci untuk mendalami implementasi Sistem Penjaminan Mutu Pendidikan pada SMA yang Terakreditasi A di Kabupaten Bengkayang.

Adapun rumusan masalah yang dibahas dalam penelitian ini yaitu: bagaimanakah sistem penjaminan mutu pendidikan pada SMA yang Ter-akreditasi A di Kabupaten Bengkayang?; dan bagaimanakah pencapaian pemenuhan Standar Nasional Pendidikan pada SMA yang Ter-akreditasi A di Kabupaten Bengkayang?.
Penelitian yang berkaitan dengan Analisis Sistem Penjaminan Mutu Pendidikan pada SMA yang terakreditasi A ini memilih lokasi penelitian di SMA N 1 Bengkayang dan SMA N 3 Bengkayang. Dua sekolah tersebut dipilih sebagai lokasi penelitian karena merupakan sekolah yang memiliki akreditasi A diantara sekolah menengah atas di Kabupaten Bengkayang dengan tahun akreditasi tahun 2019. Peringkat akreditasi ini tentunya berkaitan dengan implementasi sistem penjaminan mutu sekolah karena peringkat akreditasi dinilai berdasarkan atas pelaksanaan delapan komponen Standar Nasional Pendidikan yang telah dijalankan secara terus menerus.

\section{RUANG LINGKUP}

Di Kabupaten Bengkayang saat ini hanya ada 9 (sembilan) sekolah yang mendapatkan peringkat akreditasi A, yang salah satunya adalah SMA N 1 Bengkayang dan SMA N 3 Bengkayang. Permasalahan yang berkaitan dengan sistem penjaminan mutu pendidikan masih termasuk kendala yang belum dapat diatasi untuk meningkatkan peringkat akreditasi. Untuk itu perhatian terhadap sistem penjaminan mutu pendidikan ini perlu dikaji agar nantinya dapat memberikan manfaat kepada pihak-pihak yang berkepentingan dalam analisis sistem penjaminan mutu pendidikan khususnya bagi SMA N 1 Bengkayang dan SMA N 3 Bengkayang maupun sebagai informasi untuk satuan pendidikan lainnya sehingga kualitas sekolah dapat ditingkatkan secara berkelanjutan.

Fokus penelitian ini difokuskan pada implementasi sistem penjaminan mutu pendidikan di SMA $\mathrm{N} 1$ Bengkayang dan SMA N 3 Bengkayang yang berada di Kabupaten Bengkayang. Untuk menghindari kesalahan penafsiran dan pemahaman terhadap istilah judul: "Analisis Sistem Penjaminan Mutu Pendidikan pada SMA yang Ter-akreditasi A" yang diteliti, maka penulis harus memperjelas istilah dan batasan makna isi dari penulisan tersebut, yaitu sebagai berikut. Menurut (Simarmata, 2015) penjaminan mutu adalah proses penetapan dan pemenuhan standar mutu pengelolaan satuan pendidikan secara konsisten dan berkesinambungan sehingga yang pemangku kepentingan merasa puas. Sedangkan, (Zahrok, 2020) menyatakan bahwa karena adanya tuntutan para pemangku kepentingan akan pendidikan berkualitas tinggi, penjaminan mutu harus dipenuhi untuk menghasilkan lulusan yang berkompeten dan berkualitas. Akreditasi adalah kegiatan evaluasi kelayakan program dan/atau satuan pendidikan berdasarkan kriteria yang telah ditetapkan. Dengan demikian, penjaminan mutu pendidikan menjadi tanggung jawab semua pihak agar nilai akreditasi meningkat setiap periode dan kepercayaan pemangku kepentingan meningkat. Penyelenggaraan penjaminan mutu pendidikan dilakukan oleh satuan pendidikan dan penyelenggara satuan pendidikan di tingkat kabupaten atau kota, pemerintah daerah, dan pemerintah pusat. Tahapan penjaminan mutu 
pendidikan dimulai dengan penetapan standar mutu, pemenuhan mutu pendidikan, penyusunan rencana pemenuhan mutu pendidikan, pelaksanaan kesesuaian mutu pendidikan dan evaluasi kesesuaian mutu pendidikan.

Adapun tujuan yang ingin dicapai berdasarkan rumusan masalah dari penelitian ini adalah agar dapat menganalisis sistem penjaminan mutu pendidikan pada SMA yang Ter-akreditasi A di Kabupaten Bengkayang, serta menganalisis keberhasilan dan ketidakberhasilan pencapaian pemenuhan Standar Nasional Pendidikan pada SMA yang Ter-akreditasi A di Kabupaten Bengkayang.

\section{BAHAN DAN METODE}

Jenis penelitian yang digunakan dalam penelitian ini adalah penelitian kualitatif yang bersifat deskriptif, yang artinya dapat menghasilkan data apa adanya, dalam kondisi dimana hasilnya tidak di rekayasa atau tanpa mengubah variabel-variabel yang diteliti. Tetapi, hasil yang diperoleh lebih menekankan pada makna sesuai kenyataan yang ada di lapangan. Penelitian ini mempunyai tujuan untuk mendeskripsikan secara detail dan lebih mendalam realitas empiris berdasarkan fenomena tersebut, serta mengungkap gejala holistik kontekstual melalui pengumpulan data di lapangan dengan menggunakan peneliti itu sendiri sebagai kuncinya (Sugiyono, 2015).

Peneliti menggunakan pendekatan kualitatif untuk memperoleh data. Peneliti berupaya mengungkap proses implementasi dan peningkatan sistem penjaminan mutu pendidikan di SMA N 1 Bengkayang dan SMA N 3 Bengkayang. Peneliti menggunakan pelaksanaan siklus sistem penjaminan mutu pendidikan sebagai alat untuk mengamati dan menghasilkan data. Penelitian ini dilakukan dengan observasi, wawancara mendalam, dan dokumentasi sebagai teknik pengumpulan data. Peneliti dalam pelaksanaannya adalah alat kunci utama, karena penelitian yang benar-benar memahami kebutuhan data dan interpretasi nya selama berada di lapangan. Kemudian, peneliti memilih menggunakan uji keabsahan sumber dan teknik triangulasi data. Yang pertama adalah teknik triangulasi data untuk menguji kredibilitasnya dengan memverifikasi data yang berasal dari berbagai sumber yang relevan. Data yang diperoleh dari berbagai sumber harus di verifikasi dengan menggunakan teknik triangulasi data. Triangulasi data dalam penelitian ini dilakukan untuk memvalidasi data ataupun informasi dari berbagai sumber yaitu Kepala sekolah, tim penjaminan mutu, guru, peserta didik, dan komite sekolah. Peneliti mengidentifikasi informasi yang sama, informasi yang berbeda, dan informasi yang spesifik. Selain itu, para peneliti menarik kesimpulan dari identifikasi informasi.

Penelitian ini dilaksanakan di SMA N 1 Bengkayang dan SMA N 3 Bengkayang, yang berada di Kabupaten Bengkayang dan terletak di sebelah utara Provinsi Kalimantan Barat. Waktu penelitian dilakukan pada bulan Maret sampai dengan bulan Agustus Tahun 2021. Penelitian ini yang digunakan adalah data primer dan data sekunder. Sumber data primer ini diperoleh melalui survei dan wawancara dengan menggunakan kuesioner dan pedoman wawancara kepada para responden, terdiri dari Kepala sekolah dan tim penjaminan mutu sebagai informan utama, sedangkan guru, peserta didik, dan perwakilan komite sekolah sebagai informan pendukungnya. Sedangkan sumber data sekunder diperoleh melalui studi pustaka yang terdiri dari peraturan perundang-undangan, jurnal-jurnal penelitian, laporan ilmiah, laporan resmi pemerintah, dan bahanbahan lainnya yang relevan.

Satuan pendidikan yang telah mengimplementasikan dan membentuk tim penjaminan mutu di Kabupaten Bengkayang dapat dikatakan masih terbatas. Meskipun setiap satuan pendidikan telah mempunyai tim khusus untuk melaksanakan penjaminan mutu, seringkali tim tersebut masih belum maksimal untuk melakukan kegiatan penjaminan mutu. Dari jumlah total 33 SMA/MA yang ada di Kabupaten Bengkayang, ada 9 SMA/MA telah memiliki peringkat akreditasi A (Data Badan Akreditasi Nasional Sekolah/Madrasah Provinsi Kalimantan Barat, diakses 21 November 2021). Berikut data peringkat akreditasi pada SMA/MA yang terakreditasi A di Kabupaten Bengkayang.

Tabel 1. Peringkat Akreditasi SMA/MA di Kabupaten Bengkayang 2021

\begin{tabular}{|l|l|c|c|}
\hline No & \multicolumn{1}{|c|}{ Sekolah } & $\begin{array}{c}\text { Tahun } \\
\text { Akreditasi }\end{array}$ & Peringkat \\
\hline 1. & SMA N 1 Bengkayang & 2019 & A \\
\hline 2. & SMA N 2 Bengkayang & 2020 & A \\
\hline 3. & SMA N 3 Bengkayang & 2019 & A \\
\hline 4. & MAN 1 Bengkayang & 2019 & A \\
\hline 5. & MAN Sanggau Ledo & 2019 & A \\
\hline 6. & $\begin{array}{l}\text { SMA N 1 Sanggau } \\
\text { Ledo }\end{array}$ & 2018 & A \\
\hline 7. & SMAN 1 Ledo & 2017 & A \\
\hline 8. & SMA N 1 Seluas & 2017 & A \\
\hline 9. & $\begin{array}{l}\text { SMAS Harapan } \\
\text { Bangsa Samalantan }\end{array}$ & 2016 & A \\
\hline
\end{tabular}

Sumber: Badan Akreditasi Nasional Sekolah/Madrasah Provinsi Kalimantan Barat, 2021

Berkaitan dengan data dan uraian di atas, dalam rangka mewujudkan peningkatan sistem penjaminan mutu pendidikan, maka beberapa SMA/MA di Kabupaten Bengkayang, sebagaimana yang peneliti amati telah berupaya membangun sistem penjaminan mutu tahap demi tahap serta secara berkelanjutan.

Dalam penelitian ini menggunakan analisis data yang dikembangkan oleh (Wijaya, 2018), analisis data ini terdiri dari empat tahapan, yaitu sebagai berikut. Pertama, teknik analisis domain digunakan untuk menganalisis deskripsi topik penelitian secara umum atau pada tingkat yang dangkal, tetapi relatif utuh pada topik penelitian. Pada tahapan kedua adalah teknik analisis taksonomi yang lebih berfokus pada beberapa 
domain, sehingga memilih domain tersebut menjadi subdomain dan bagian yang lebih spesifik dan terperinci, yang pada umumnya merupakan kelompok yang memiliki kesamaan. Pada tahapan yang ketiga adalah teknik analisis komponensial digunakan dalam analisis kualitatif untuk menganalisis unsur-unsur yang memiliki hubungan kontraktual satu sama lain dalam domain yang telah ditentukan untuk dianalisis secara lebih rinci. Elemen kontras atau elemen akan dipilih oleh peneliti dan kemudian dicari istilah yang dapat menampungnya. Pada tahapan terakhir dalam analisis data adalah teknik analisis kultural yang merupakan tahapan dalam arti bagaimana peneliti beradaptasi dengan masalah yang diteliti, mencari dan membuka peluang munculnya data baru atau informasi baru, dan lain-lain. Dengan demikian, tahapan ini menciptakan dasar yang menggambarkan situasi sosial atau topik penelitian yang selama ini tidak jelas dan menjadi semakin jelas setelah penelitian dilakukan.

\section{PEMBAHASAN}

Penelitian ini dilakukan di Kabupaten Bengkayang dalam lingkup pendidikan, sehingga responden pada penelitian ini diseleksi berdasarkan kebutuhan peneliti akan sumber data yang relevan dengan pelaksanaan penelitian mengenai sistem penjaminan mutu pendidikan. Bagian berikut menjelaskan hasil dan diskusi penelitian ini.

\subsection{Sistem Penjaminan Mutu Pendidikan pada SMA} yang Ter-akreditasi A di Kabupaten Bengkayang Implementasi sistem penjaminan mutu di SMA N 1 Bengkayang dan SMA N 3 Bengkayang sudah dilaksanakan dengan ideal. Siklus penjaminan mutu yang dilaksanakan oleh satuan pendidikan terdiri dari 5 tahapan yaitu penetapan standar mutu, pemetaan mutu, penyusunan rencana pemenuhan, pelaksanaan pemenuhan dan evaluasi/audit mutu (Dewi, 2016). Siklus sistem penjaminan mutu pendidikan dasar dan menengah yang tertuang juga dalam Peraturan Menteri Pendidikan dan Kebudayaan No 28 Tahun 2016 tentang Sistem Penjaminan Mutu Pendidikan Dasar dan Menengah dan dijelaskan pada Pedoman Umum Sistem Penjaminan Mutu Pendidikan Dasar dan Menengah sebagai berikut.

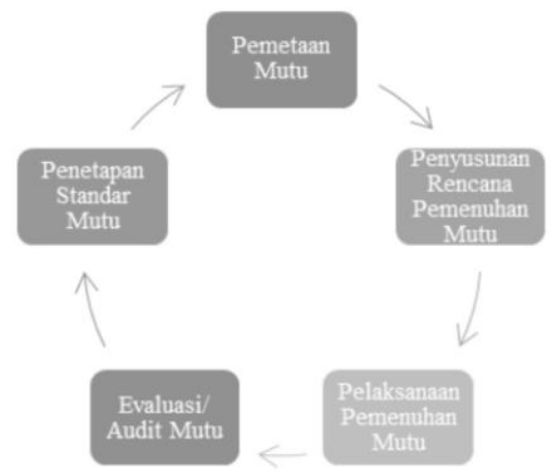

Gambar 1. Siklus Sistem Penjaminan Mutu Pendidikan
Secara umum pelaksanaan sistem penjaminan mutu di SMA N 1 Bengkayang dan SMA N 3 Bengkayang, mencakup: penetapan standar mutu sesuai dengan kriteria minimal dalam Standar Nasional Pendidikan (SNP) dengan melibatkan seluruh komponen sekolah, pemetaan mutu melalui kegiatan evaluasi diri, penyusunan rencana mutu berdasarkan hasil pemetaan mutu yang telah dilakukan, pelaksanaan rencana pemenuhan mutu dengan terwujudnya budaya mutu, serta evaluasi atau audit pelaksanaan rencana pemenuhan mutu untuk meningkatkan mutu sekolah secara terus menerus. Dari sebagian besar komponen sekolah yang ikut terlibat menyatakan bahwa sistem penjaminan mutu dilaksanakan secara konsisten setiap tahunnya sesuai dengan siklus penjaminan mutu pendidikan.

Penetapan standar mutu di SMA N 1 Bengkayang dan SMA N 3 Bengkayang dibuktikan dengan adanya 8 Standar Nasional Pendidikan (SNP) yang telah ditetapkan yaitu: Standar Kompetensi Lulusan, Standar Isi, Standar Proses, Standar Penilaian, Standar Pendidik dan Tenaga Kependidikan, Standar Pengelolaan, Standar Sarana dan Prasarana, dan Standar Pembiayaan. Dalam penetapan standar mutu ini Kepala sekolah membentuk tim penjaminan mutu melalui Surat Keputusan Kepala Sekolah. Beberapa rincian tugas tim penjaminan mutu sekolah diantaranya: merumuskan dan menyusun standar dengan menjadikan visi dan misi sekolah sebagai titik tolak dan tujuan akhir, mulai dari merancang hingga menetapkan standar, serta mempelajari semua peraturan perundang-undangan dan peraturan lain yang relevan, menyusun Evaluasi Diri Sekolah (EDS) untuk memetakan kondisi mutu sekolah berbasis pada Standar Nasional Pendidikan (SNP), menyusun laporan analisis terhadap hasil kegiatan pemetaan mutu, menyusun dan melaksanakan program Rencana Pengembangan Sekolah (RPS), Rencana Kerja Sekolah (RKS), Rencana Kegiatan dan Anggaran Sekolah (RKAS), melakukan monitoring dan pengendalian catatan mutu untuk meningkatkan mutu sekolah. Dasar yang digunakan oleh tim penjaminan mutu sekolah dalam penetapan standar mutu dengan melibatkan seluruh pemangku kepentingan baik internal maupun eksternal. Temuan dari penelitian ini memiliki beberapa kesamaan dengan temuan (Nugraha, 2018) yang menunjukkan bahwa penjaminan mutu pendidikan di sekolah tidak dapat berjalan dengan baik tanpa adanya budaya mutu pada seluruh komponen sekolah.

Berdasarkan hasil pengamatan, pemetaan mutu di SMA N 1 Bengkayang dan SMA N 3 Bengkayang dibuktikan dengan adanya dokumen hasil Evaluasi Diri Sekolah (EDS). Tim penjaminan mutu yang telah ditunjuk mengisi instrumen evaluasi diri sekolah pada aplikasi EDS yang telah disediakan oleh Ditjen PAUD, Dikdas, dan Dikmen Kementerian Pendidikan dan Kebudayaan. Berdasarkan pelaporan EDS, SMA N 1 Bengkayang dan SMA N 3 Bengkayang telah menghasilkan rapor mutu dengan capaian mutu delapan 
SNP yang sudah sangat baik. Namun, walaupun hasilnya sudah sangat baik, pihak sekolah akan tetap terus menerus mengupayakan peningkatan mutu sekolah, bahkan melampaui SNP. Partisipasi seluruh komponen sekolah akan memudahkan proses pemenuhan mutu. Dengan demikian, rapor mutu yang dihasilkan juga hasilnya pasti memuaskan. Rapor mutu yang baik akan menghasilkan analisis yang baik yang seterusnya dapat menjadi koridor pengawal pengembangan sekolah (MY, 2019).

Penyusunan rencana pemenuhan mutu dibuktikan dengan adanya RKS, RKAS, dan dokumen 1 yang telah disusun oleh tim penyusun, yang diantaranya juga merupakan tim penjaminan mutu. Dalam penyusunan perencanaan program peningkatan mutu sekolah baik di SMA N 1 Bengkayang maupun SMA N 3 Bengkayang telah melibatkan pemangku kepentingan internal seperti Kepala Sekolah, guru, perwakilan tenaga kependidikan, disertai juga dengan melibatkan pemangku kepentingan eksternal seperti, komite sekolah, pengawas sekolah, dan perwakilan tokoh masyarakat. Pihak-pihak yang terlibat telah didokumentasikan dengan baik dalam berita acara serta masukan dan saran terekam dalam notulensi. Penyusunan rencana mutu ini dapat dijadikan sebagai panduan bagi seluruh pihak terkait, kepala sekolah, guru, maupun tenaga kependidikan untuk mengetahui mekanisme rencana pemenuhan mutu serta mengimplementasikannya dalam tugas pokok dan fungsi masing-masing agar budaya mutu dapat terwujud dan visi misi sekolah tercapai. Hal serupa juga dikemukakan oleh (Rahwati, 2019) bahwa untuk mencapai visi dan misi sekolah, termasuk dalam hal ini peningkatan kualitas guru, semua sekolah harus menyusun dan menetapkan rencana program sekolah dan kegiatan sekolah sesuai dengan rencana pengembangan sekolah.

Pelaksanaan rencana pemenuhan mutu di SMA N 1 Bengkayang dan SMA N 3 Bengkayang yang melibatkan seluruh komponen sekolah dibuktikan dengan adanya kerja sama dari Kepala sekolah, guru, tenaga kependidikan, dan pengawas sekolah, selain itu juga adanya dukungan dari peserta didik maupun lulusan. Dalam hal ini, peran Kepala sekolah adalah mengarahkan, mengoordinasi, serta mendorong seluruh warga sekolah untuk dapat mewujudkan budaya mutu di sekolah sehingga mutu sekolah terus meningkat. Keterlibatan kepala sekolah dalam proses penyusunan dan validasi isian instrumen sistem penjaminan mutu di sekolah dapat dijadikan gambaran kemampuan teknis dan manajerial kepala sekolah (Raharjo dkk 2019). Peran guru dan tenaga kependidikan tidak kalah pentingnya guna mendukung kelancaran proses penjaminan mutu pendidikan karena guru merupakan ujung tombak untuk menentukan keberhasilan pendidikan yang berkualitas. Para guru baik guru di SMA N 1 Bengkayang maupun guru SMA N 3 Bengkayang telah melaksanakan tugas dan tanggung jawabnya dengan menjadi pendidik yang professional dan memberikan pelaporan atas dokumendokumen pendukung dan tugasnya sehari-hari. Selain itu, ada juga dukungan yang diberikan oleh komite sekolah dalam memberikan masukan dan saran mengenai kebijakan dan aturan yang telah ditetapkan, serta adanya peran pengawas sekolah yang salah satunya adalah memantau dan mengevaluasi penyelenggaraan sistem penjaminan mutu terutama membina guru-guru dalam proses pembelajaran, kemudian hasilnya berupa pelaporan perkembangan sekolah.

Berdasarkan hasil penelitian, evaluasi/audit pemenuhan mutu di SMA N 1 Bengkayang dan SMA N 3 Bengkayang telah berlangsung secara rutin setiap tahun ajaran. Evaluasi pemenuhan mutu ini dilakukan sebagai salah satu bentuk pengimplementasian sistem penjaminan mutu pendidikan agar Standar Nasional Pendidikan terpenuhi secara sistematis dan berkelanjutan. Selain itu juga, bertujuan untuk tumbuh dan berkembang budaya mutu di sekolah secara terus menerus. Evaluasi dilakukan secara bertahap dan sistematis sesuai dengan mekanisme yang telah ditetapkan, dengan maksud untuk mengevaluasi kinerja dan program baik pada SMA N 1 Bengkayang maupun SMA N 3 Bengkayang, dan merumuskan rekomendasi perbaikannya apabila diperoleh beberapa temuan yang menjadi rekomendasi untuk segera dilakukan di tahun selanjutnya. Dengan demikian, pihak sekolah dapat mengetahui sejauh mana pencapaian standar mutu selama setahun dan juga dapat dijadikan sebagai bahan masukan atau evaluasi diri untuk perbaikan kinerja sekolah secara berkelanjutan. Hasil evaluasi dari EDS selalu dijadikan laporan analisis terhadap hasil kegiatan pemetaan mutu yang menjadi referensi Kepala Sekolah dalam merancang RPS maupun kebijakan-kebijakan yang diperlukan pada tahun berikutnya. Menurut (Hajar, 2017) menyatakan bahwa kegiatan evaluasi pemenuhan mutu juga dilakukan diskusi untuk saling menyampaikan keluhan yang dirasakan oleh personil yang terlibat dalam pelaksanaan program, sehingga dapat ditemukan permasalahan baik yang dirasakan masing-masing individu maupun kelompok serta semua hal yang mendukung pelaksanaan program.

\subsection{Keberhasilan dan Ketidakberhasilan Pencapaian Pemenuhan Standar Nasional Pendidikan pada SMA yang Ter-akreditasi A di Kabupaten Bengkayang}

Pada data referensi Kementerian Pendidikan dan Kebudayaan Jumlah Data SMA Per Kabupaten/Kota di Kabupaten Bengkayang berjumlah 33 sekolah yang terdiri dari SMA Negeri ada 26 sekolah, sedangkan SMA Swasta ada 7 sekolah (Data Referensi Kemendikbud, Agustus 2021). Berdasarkan hasil telaah dokumen juga menunjukkan bahwa status peringkat akreditasi SMA N 1 Bengkayang memiliki akreditasi A, berdasarkan sertifikat 748/BAN-SM/SK/2019, dan SMAN 3 Bengkayang memiliki akreditasi A, berdasarkan sertifikat 1335/BAN-SM/SK/2019. Dengan demikian, salah satu yang menjadi indikator keberhasilan SMAN 1 Bengkayang dan SMA N 3 Bengkayang telah 
meningkatkan mutu pendidikan adalah peringkat akreditasi.

Dari hasil pengamatan dapat diidentifikasi pelbagai faktor pendukung keberhasilan, faktor penghambat tercapai nya, dan identifikasi akar masalah pemenuhan Standar Nasional Pendidikan pada SMA N 1 Bengkayang dan SMA N 3 Bengkayang.

Sejumlah faktor pendukung keberhasilan yang dapat diidentifikasi, yaitu: seluruh komponen sekolah memiliki komitmen yang tinggi untuk mewujudkan budaya mutu, adanya penyusunan dan peninjauan ulang RPS, adanya rencana kerja tahunan yang menjadi realisasi penyelenggaraan sistem penjaminan mutu, tim penjaminan mutu bekerja sama untuk menyusun EDS dan dokumen pendukung lainnya, pelibatan pemangku kepentingan internal dan eksternal, Program dan kegiatan pemenuhan mutu dilaksanakan sesuai dengan rencana yang telah ditetapkan, Kepala sekolah merespons hasil EDS dengan langkah-langkah yang konkrit dan berkomitmen untuk menindaklanjuti rekomendasi perbaikannya, serta adanya mekanisme EDS melalui rapat rutin setiap akhir tahun sehingga upaya tindak lanjut dapat segera dilakukan.

Sedangkan sejumlah faktor penghambat tercapai nya yang dapat diidentifikasi, yaitu: terjangkaunya akses internet dalam proses pengisian pemetaan mutu secara online, pemenuhan standar sarana dan prasarana belum optimal, pemahaman pihak-pihak yang terlibat dalam pelaksanaan siklus sistem penjaminan mutu masih kurang, masih minimnya guru yang dapat dilibatkan dalam tim penjaminan mutu, masih minimnya jumlah guru maupun tenaga kependidikan, serta masih ada beberapa butir pernyataan yang pengisiannya belum sesuai dengan kondisi riil di lapangan.

Sejumlah akar masalah yang dapat diidentifikasi, yaitu: jaringan internet yang kurang lancar dan tidak stabil di daerah perbatasan, keterbatasan anggaran untuk pengadaan sarana dan prasarana yang memadai sebagai penunjang proses pembelajaran, masih ada beberapa guru yang kesulitan melakukan evaluasi diri sekolah, kesulitan manajemen waktu untuk melaksanakan setiap program sesuai standar karena tugas administratif guru sudah terlampau banyak, keterbatasan sumber daya untuk mengimplementasikan sistem penjaminan mutu sekolah dengan optimal, serta tidak semua butir pernyataan pemetaan mutu sesuai dengan kondisi sekolah yang ada di daerah, khususnya daerah perbatasan.

Berdasarkan hasil analisis faktor pendukung keberhasilan, faktor penghambat tercapainya, dan identifikasi akar masalah pemenuhan Standar Nasional Pendidikan pada SMA N 1 Bengkayang dan SMA N 3 Bengkayang kiranya dapat ditentukan beberapa tindak lanjut yang dapat dilakukan, antara lain: memfasilitasi sarana yang memadai pada saat proses pelaksanaan sistem penjaminan mutu, terutama pada saat pemetaan mutu, memotivasi dan memberi dukungan penuh kepada pihak-pihak yang terlibat untuk melakukan EDS, pihak sekolah dapat memberdayakan tenaga yang ada untuk dapat mengoptimalkan sistem penjaminan mutu pendidikan, mengalokasikan anggaran dari berbagai sumber lainnya, seperti dana BOS, partisipasi masyarakat ataupun orang tua siswa, bantuan hibah dari pemerintah maupun nonpemerintah, serta memberikan sosialisasi atau pelatihan pengisian EDS kepada guru dan siswa yang ditunjuk sebagai responden. Upaya untuk menindaklanjuti berbagai kendala pada SMA $\mathrm{N} 1$ Bengkayang dan SMA N 3 Bengkayang dapat dilaksanakan oleh Kepala Sekolah, guru, komite sekolah, dan pengawas sekolah. Tindak lanjut juga dapat dilakukan untuk meningkatkan pemenuhan mutu dengan cara: menyelenggarakan rapat koordinasi secara rutin untuk membangun budaya mutu, melakukan revisi terhadap standar yang perlu ditingkatkan, melakukan evaluasi terhadap isi standar sehingga menjadi standar yang baru yang lebih tinggi dari standar sebelumnya, serta melakukan langkah-langkah pengembangan sistem yang dibutuhkan.

\section{KESIMPULAN}

Di Kabupaten Bengkayang terdapat dua SMA yang memiliki peringkat akreditasi A, antara lain SMA N 1 Bengkayang dan SMA N 3 Bengkayang yang dapat dikatakan sistem penjaminan mutu pendidikannya sudah berjalan dengan baik. Selain itu, pada kedua sekolah tersebut dapat dibuktikan bahwa pengelolaan kebijakan, regulasi, program, kegiatan, telah sesuai dengan tata cara prosedur yang ditetapkan mengenai Standar Nasional Pendidikan, serta dapat dipercaya dan disepakati bersama oleh seluruh komponen sekolah, meskipun masih ada beberapa kendala dalam penerapannya. Namun, untuk mengatasi beberapa kendala tersebut, dilakukan upaya tindak lanjut yang dapat dilaksanakan oleh Kepala Sekolah, guru, komite sekolah, dan pengawas sekolah. Kondisi ini tentu saja harus menjadi perhatian semua pihak agar budaya mutu menjadi prioritas. Setiap program maupun kegiatan yang dilakukan sekolah sebaiknya menggunakan prinsip pengembangan sistem penjaminan mutu berkelanjutan agar tujuan nasional pendidikan yang bermutu tinggi dapat terwujud.

\section{SARAN}

Sekolah-sekolah yang telah mendapatkan akreditasi A dapat terus menerus melakukan evaluasi terhadap Standar Nasional Pendidikan sekaligus melakukan revisi terhadap isi standar, sehingga standar yang ada selalu terpenuhi atau bahkan terlampaui. Ini merupakan tahapan penting yang harus dilakukan oleh sekolah untuk meningkatkan sistem penjaminan mutu pendidikan. Selain itu, Pemerintah dapat memberikan kontribusi nya dengan memerhatikan dan meningkatkan serta mengupayakan mekanisme maupun isi pernyataan instrumen pemetaan mutu yang dapat menjangkau kondisi seluruh sekolah khususnya bagi sekolah-sekolah di daerah terpencil. 


\section{DAFTAR PUSTAKA}

Asmara, Rahidi. 2015. “Analisis Implementasi Delapan Standar Nasionalpendidikan Pada SMP Yang Terakreditasi A" 9 (Manajer Pendidikan): 173-84.

Asy'ari Mukaromah, HasyimLailil. 2019. "Jurnal Kependidikan:” Jurnal Kependidikan 7: 111-26.

Badan Akreditasi Nasional Sekolah/ Madrasah Provinsi Kalimantan Barat. http://bansmprovkalbar.or.id/index.php/Akreditasi/ index/105/Data-Akreditasi.html, diakses 21 November 2021.

Data Referensi Kemendikbud. https://referensi.data.kemdikbud.go.id/index11.php ?kode $=130800 \&$ level=2, diakses 26 Agustus 2021 .

Dewi, Yetty Fatri. 2016. "Penjaminan Mutu Pendidikan Melalui Sistem Penjaminan Mutu Internal (SPMI)." Education Management 1: 1-4.

Hajar, Ruyatul. 2017. "Implementasi Penjaminan Mutu Pendidikan Dalam Meningkatkan Kinerja Madrasah: Studi Di MTs Assurur Dan MTs Arrohmah Kota Tasikmalaya." Indonesian Journal of Education Management and Administration Review IJEMAR 1 (1): 89-98.

Muhammad, Hamid. 2016. Pedoman umum sistem penjaminan mutu pendidikan dasar dan menengah. Direktorat Jenderal Pendidikan Dasar dan Menengah, Jakarta.

MY, Nurmaini. 2019. "Meraih Mutu Sekolah Melalui Data Mutu: Suatu Tinjauan." Jurnal Ilmiah Universitas Batanghari Jambi 19 (2): 347. https://doi.org/10.33087/jiubj.v19i2.677.

Nugraha, RL. 2018. "Pelaksanaan Penjaminan Mutu Pendidikan Di SMPN 1 Bantarkawung Kabupaten Brebes" 4 (Masters thesis, FIP Universitas Negeri Malang): 75496735.

Pemerintah Republik Indonesia. 2016. Peraturan Menteri Pendidikan dan Kebudayaan No 28 Tahun 2016 tentang Sistem Penjaminan Mutu Pendidikan Dasar dan Menengah. Presiden Indonesia.

Pemerintah Republik Indonesia. 2021. Peraturan Pemerintah Republik Indonesia Nomor 57 Tahun
2021 tentang Standar Nasional Pendidikan. Presiden Indonesia.

Raharjo, dkk. 2019. Sistem Penjaminan Mutu Pendidikan. Jurnal Panjar. Vol. 1.

Rahmania, Ika. 2020. Implementasi Sistem Penjaminan Mutu Internal Untuk Meningkatk an $M U t u$ Pendidik an Di Smp Negeri 21 Malang.

Rahwati, Dedeh. 2019. "Implementasi Sistem Penjaminan Mutu Pendidikan Dalam Meningkatkan Mutu Pendidikan Dasar." Indonesian Journal of Education Management and Administration Review 3 (Management and Administration Review): 13-24. https://doi.org/http://dx.doi.org/10.4321/ijemar.v3i 1.2945 .

Simarmata, Jonner. 2015. "Analisis Implementasi Penjaminan Mutu Di Sma Negeri 3 Kota Jambi." Jurnal Ilmiah Universitas Batanghari Jambi 15 (4): 54-62.

Sugiyono. 2015. Metode Penelitian Kuantitatif, Kualitatif, dan R\&D. Bandung: ALFABETA.

Wijaya, Hengki. 2018. "Ringkasan Dan Ulasan Buku Analisis Data Penelitian Kualitatif (Prof. Burhan Bungin)." ResearchGate, no. March: 1-45.

Zahrok, Asnaul Lailina Nikmatuz. 2020. "Implementasi Sistem Penjaminan Mutu Internal Di Sekolah Menengah Kejuruan (SMK).” Jurnal Akuntabilitas Manajemen Pendidikan 8 (2): 196-204. https://doi.org/10.21831/jamp.v8i2.31288.

\section{UCAPAN TERIMA KASIH}

Ucapan terima kasih diberikan kepada Pusat Riset dan Pengabdian pada Masyarakat (PRPM) Institut Shanti Bhuana atas segala dukungannya. Terima kasih juga diberikan kepada SMA N 1 Bengkayang dan SMA N 3 Bengkayang atas kerja sama baiknya dalam pelaksanaan penelitian ini. 